\title{
Fatty acid content of Antarctic krill Euphausia superba at South Georgia related to regional populations and variations in diet
}

\author{
G. C. Cripps ${ }^{1, *}$, J. L. Watkins ${ }^{1}$, H. J. Hill ${ }^{2}$, A. Atkinson ${ }^{1}$ \\ ${ }^{1}$ British Antarctic Survey, Natural Environmental Research Council, High Cross, Madingley Road, Cambridge, CB3 0ET, \\ United Kingdom \\ ${ }^{2}$ University of East London, Longbridge Road, Dagenham, RM8 2AS, United Kingdom
}

\begin{abstract}
The fatty acid content of Antarctic krill Euphausia superba from South Georgia was investigated during January and February 1996, a period of relatively low algal biomass. Cluster analysis of the fatty acid data revealed 3 regionally distinct groups of krill. Group A consisted primarily of subadults (median length $42 \mathrm{~mm}$ ) and was characterised by high proportions of 14:0, 16:0 and 18:1(n-9) fatty acids. Group B comprised mainly juveniles and a small proportion of adults (median length $33 \mathrm{~mm}$ ) and had a fatty acid profile similar to that of Group A. The largest group, Group C (8 of 14 stations, mostly to the east of the survey area), was almost exclusively juveniles plus a small number of sub-adults (median length $29 \mathrm{~mm}$ ) and had unusually high percentages of polyunsaturated fatty acids [PUFA; 18:4(n-3), 20:5(n-3) and 22:6(n-3)]. Krill from Group $C$ had the lowest total fatty acid concentrations (150 to $722 \mathrm{mg} \mathrm{kg}^{-1}$ ). These krill were surviving on the lowest algal biomass in the region and had probably resorted to carnivory on PUFA rich copepods. The pattern of fatty acids in krill from Groups $A$ and $B$ resembled that of krill collected from a diatom bloom in the Bellingshausen Sea, but the concentrations were generally lower. The well fed krill from the Bellingshausen Sea showed small variations in fatty acid content associated with sex and maturity, but the South Georgia results indicated that diet can have a greater impact on fatty acid content than sex and maturity stages. Fatty acid profiles were indicative of food regimes that were so distinct that the krill probably originated from spatially independent groups.
\end{abstract}

KEY WORDS: Antarctic $\cdot$ Krill $\cdot$ Diet - Fatty acids $\cdot$ Regional populations $\cdot$ South Georgia

\section{INTRODUCTION}

Antarctic krill Euphausia superba are abundant and widespread zooplankton of the Southern Ocean and a primary food source for many species of birds, fish, seals, squid and whales (El-Sayed 1985). Thus, they are a key component of the Southern Ocean ecosystem at the centre of the food web (Laws 1985, Marchant \& Murphy 1994). E. superba (hereafter 'krill') are known as omnivores but are considered to be essentially herbivorous when grazing on phytoplankton blooms (Price et al. 1988, Hopkins et al. 1993). They appear to

\footnotetext{
•E-mail: gccr@pcmail.nerc-bas.ac.uk
}

utilise efficiently whatever food is available (Schnack 1985) and have physiological mechanisms to enable them to survive periods when food is scarce or absent (Ikeda \& Dixon 1982, Quetin \& Ross 1991, Quetin et al. 1994, Torres et al. 1994, Hagen et al. 1996).

The phytoplankton population of the Southern Ocean is generally characterised by a background of low biomass, composed of small diatoms and flagellates, on which blooms of diatoms are superimposed (Smetacek et al. 1990, Clarke \& Leakey 1996). These blooms consist predominantly of large diatoms and provide abundant food for the grazing zooplankton such as krill. It has been observed that krill dietary throughput increases markedly in a bloom (Perissinotto et al. 1997) and that assimilation may be less effi- 
cient when feeding on a localised high algal biomass. The algal food source of krill is, in the main, patchy and they may resort to carnivory, lower their metabolism or show evidence of shrinking when phytoplankton are scarce (Price et al. 1988, Quetin \& Ross 1991, Atkinson \& Snÿder 1997, Pakhomov et al. 1997, Perissinotto et al. 1997). Krill regularly occur in high density at South Georgia (Brierley et al. 1997, Watkins et al. in press) and, thus, may be able, through grazing, to control locally the biomass of phytoplankton populations (Quetin \& Ross 1985).

To date, studies on the lipids and the component fatty acids of krill have been general surveys (e.g. Bottino 1975, Reinhardt \& Van Vleet 1986), comparisons between sex and maturity stages (e.g. Clarke 1984, Pond et al. 1995, Virtue et al. 1996), and a spatial study (Mayzaud 1997). Virtue et al. (1993) suggested that biochemical signatures can provide information on food sources and feeding ground after detecting changes in the fatty acid profile of krill when fed a controlled algal diet under laboratory conditions. Mayzaud (1997) found the spatial variation in krill triglycerides to be attributable to phytoplankton in the diet. However, Cripps \& Hill (1998) found that the fatty acid profile changed very little with changing diet in the field in krill from under the sea-ice and krill from the open ocean. The fatty acid composition of many algal classes which form the main portion of krill diet are well known (Sargent et al. 1987, Volkman et al. 1989, Viso \& Marty 1993) and have been used to follow diet induced changes in other zooplankton, notably copepods (Sargent \& Falk-Petersen 1981, Graeve et al. 1994a), including several Antarctic species (e.g. Graeve et al. 1994b, Kattner et al. 1994, Cripps \& Hill 1998).

There has been a paucity of work on the fatty acids of euphausids which may be partly due to the concern that, if concentrations of lipid classes vary with maturity and sex, then the pattern of fatty acids may do so as well. Triacylglycerols (TAG) and phospholipids (PL) can be higher in female krill (Pond et al. 1995. Mayzaud et al. 1998) and the highest total lipid content has been recorded in juveniles and gravid females (Clarke 1980, 1984, Virtue et al. 1996). Some variation in the fatty acid patterns with maturity and sex has been reported in krill by Clarke (1980) and Virtue et al. (1996), such as a higher proportion of the polyunsaturated fatty acid (PUFA) 20:5(n-3) in adult males. In this study, the variation in the fatty acid content is related to the spatial distribution of krill and the available diet as well as to maturity and sex. The results are discussed in comparison to krill which had been feeding on a diatom bloom in the Bellingshausen Sea.

The physical oceanography and the dynamics of the phytoplankton and zooplankton populations of the

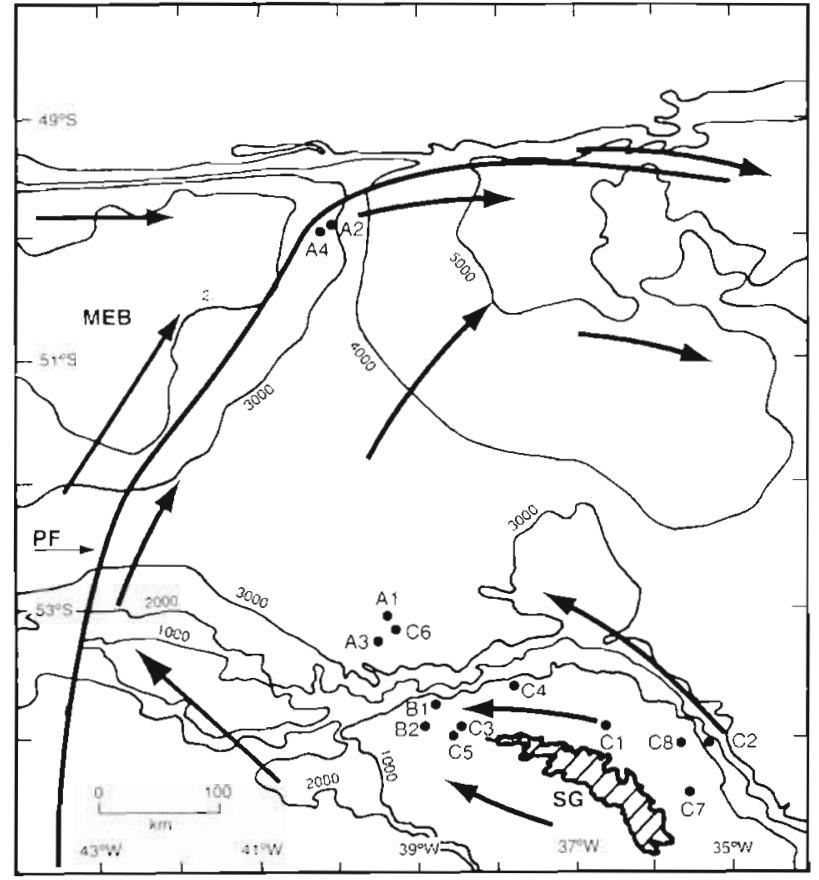

Fig. 1 Study area to the north of the island of South Georgia (SG) in the South Atlantic Ocean showing the locations of the sample stations ( $\bullet$, major currents (large arrows), the Maurice Ewing Bank (MEB) and the Antarctic Polar Front (PF) (data extracted from Trathan et al. 1997)

Southern Ocean to the north of South Georgia (Fig. 1) have been studied for a number of years (Hardy 1967 , Priddle et al. 1986, 1995, Whitehouse et al. 1996, Trathan et al. 1997). The ocean to the north of South Georgia is dominated by the Antarctic Circumpolar Current flowing from the southwest and Weddell/ Scotia Sea water flowing from the southeast along the north coast of the island. This Weddell/Scotia water appears to deflect the Antarctic Circumpolar Current to the north towards the Maurice Ewing Bank. The shelf break to the north of the island is generally a highly productive area where the spring bloom is regularly dominated by large diatoms (>20 $\mu \mathrm{m})$.

\section{METHODS}

Field sampling for krill Euphausia superba was carried out at 14 stations to the north of South Georgia during January and February 1996 (Fig. 1) and at 1 location in the Bellingshausen Sea $\left(67^{\circ} 30^{\prime} \mathrm{S}, 85^{\circ} 00^{\prime} \mathrm{W}\right)$ in December 1992 during a diatom bloom close to the Marginal Ice Zone. Krill were collected from the RRS 'James Clark Ross' by oblique hauls of a rectangular midwater trawl (RMT, nominal opening $8 \mathrm{~m}^{2}$ ) deployed to a depth of $250 \mathrm{~m}$, or in shallower water to within $20 \mathrm{~m}$ 
of the bottom. Krill from the Bellingshausen Sea were sorted into juveniles, sub-adult males and females and adult males and females before analysis (Morris et al. 1988). Whilst krill representing all maturity and sex stages were present in the Bellingshausen Sea, this was not the case at South Georgia, where juveniles were predominant at many of the stations. Krill from each station at South Georgia were pooled so as to be representative of the local population. Microplankton was sampled by filtration of seawater collected by Niskin bottles at $30 \mathrm{~m}$ depth. This was size fractionated onto ashed glass fibre membranes (Whatman grade $\mathrm{GF} / \mathrm{F}$, nominal retention $0.7 \mu \mathrm{m}$ ) and nylon membranes (nominal retention $20 \mu \mathrm{m}$ ) arranged in series with a $200 \mu \mathrm{m}$ nylon mesh prefilter.

The analytical protocols were based on established procedures (Christie 1982). In brief, krill samples (20 g wet mass) were digested in methanolic potassium hydroxide, the resulting liquor was acidified with $2 \mathrm{M}$ hydrochloric acid and the fatty acids were partitioned into hexane (see Virtue et al. 1993). The hexane extract was evaporated to dryness under a stream of nitrogen and redissolved in $14 \%$ boron trifluoride in methanol. This mixture was refluxed for 2 min to prepare the methyl esters of the fatty acids. The fatty acid methyl esters were then extracted into hexane, purified with Isolute ${ }^{\circledast}$ silica solid phase extraction cartridges (Cripps \& Tarling 1997) and analysed by capillary gas chromatography against a suite of analytical standards (Sigma Chemical Co.).

Phytoplankton collected on the filter membranes were extracted with acetone $(1 \mathrm{ml})$, using an ultrasonic cell disrupter. The acetone solution was centrifuged and the supernatant analysed for chloropigments and carotenoids by HPLC using a method developed from that of Mantoura \& Llewellyn (1983). The carotenoids were identified by comparison of retention times to algae with well known pigment profiles (Wright et al. 1991) grown from the following cultures supplied by the Plymouth Marine Laboratory: Amphidinium carterae, Chroomonas salina, Dunaliella tertiolecta, Emiliana huxleyi, Phaeodactylum tricor- nutum and Porphorydium purpurum. The fatty acid methyl esters were prepared from the phytoplankton extracts and analysed as above for krill.

Hierarchical cluster analysis was performed on the krill fatty acid data set using the MINITAB ${ }^{\circledast}$ statistical software package (Minitab Inc. 1994). This is a multivariate procedure for classifying groups, when the groups are not initially known. The resulting clusters are then depicted in a dendrogram. Principal Components Analysis (PCA) was carried out using the same software package on the data set which combined the results for fatty acids in phytoplankton from South Georgia, krill from South Georgia and krill from the Bellingshausen Sea. PCA is a data reduction technique which is used to identify a small set of variables which account for most of the variance in the original data set. Component scores were subsequently calculated from the first 3 principal components for each sample and plotted as a 3-D scattergram.

\section{RESULTS}

\section{Characterisation of the phytoplankton}

The phytoplankton biomass (measured as total chlorophyll a) was relatively low compared to previous years at South Georgia (Priddle et al. 1997). There were patches of small diatoms $(<20 \mu \mathrm{m})$ at Stns A1, B1, $\mathrm{B} 2, \mathrm{C} 4$ and C5 (1.3 to $5.2 \mu \mathrm{g} \mathrm{l^{-1 }}$ as chlorophyll $a$; Table 1 ). Phaeopigments (predominantly pyrophaeophorbide a) only were detected in the water column at Stns A1, A2, $\mathrm{C} 2$ and $\mathrm{C} 6$ and at low concentrations (25 to $139 \mathrm{ng} \mathrm{l}^{-1}$ ).

The major carotenoid algal markers of the $<20 \mu \mathrm{m}$ fraction were fucoxanthin (from diatoms), hexanoylfucoxanthin (from prymnesiophytes) and butonoylfucoxanthin (from chrysophytes). By applying a series of algorithms used by Peeken (1997) developed from earlier work by Letelier et al. (1993), the contribution of each species group (as chlorophyll a) was estimated. Diatoms, prymnesiophytes and chrysophytes comprised over $90 \%$ of the algal population at all the sta-

Table 1. Chlorophyll a concentrations contributed by algal groups present at krill sampling stations, ng $!^{-1}\left({ }^{\circ}<20 \mu m,{ }^{\prime \prime}>20 \mu m\right)$

\begin{tabular}{|c|c|c|c|c|c|c|c|c|c|c|c|c|c|c|}
\hline Stn & A1 & A2 & A.3 & A4 & B1 & $\mathrm{B} 2$ & $\mathrm{C} 1$ & $\mathrm{C} 2$ & $\mathrm{C} 3$ & $\mathrm{C} 4$ & $\mathrm{C5}$ & C6 & $\mathrm{C7}$ & $\mathrm{C} 8$ \\
\hline Dinoflagellates & 0 & 0 & 0 & 0 & 0 & 0 & 0 & 0 & 0 & 0 & 399 & 0 & 0 & 0 \\
\hline Chrysophytes & 0 & 60 & 0 & 70 & 0 & 327 & 0 & 18 & 4 & 817 & 1312 & 0 & 7 & 2 \\
\hline Small diatoms " & 1219 & 375 & 158 & 269 & 1698 & 1271 & 657 & 120 & 174 & 2626 & 3511 & 76 & 224 & 243 \\
\hline Pymnesiophytes & 544 & 171 & 130 & 341 & 27 & 23 & 0 & 86 & 34 & 25 & 22 & 12 & 24 & 6 \\
\hline Chlorophytes & 0 & 0 & 0 & 0 & 0 & 0 & 9 & 0 & 0 & 0 & 0 & 0 & 0 & 0 \\
\hline Large diatoms ". & 593 & 661 & 0 & 8 & 0 & 833 & 0 & 0 & 345 & 0 & 0 & 0 & 0 & 0 \\
\hline Total chlorophyll a & 2356 & 1267 & 289 & 688 & 1725 & 2453 & 666 & 224 & 556 & 3468 & 5244 & 88 & 255 & 251 \\
\hline Total phaeopigments & 25 & 139 & 0 & 0 & 0 & 0 & 0 & 55 & 0 & 0 & 0 & 84 & 0 & 0 \\
\hline
\end{tabular}


Table 2. Fatty acid concentrations in phytoplankton at krill sampling stations, $\mu \mathrm{g}^{-1}$

\begin{tabular}{|c|c|c|c|c|c|c|c|c|c|c|c|c|c|c|}
\hline Stn & A 1 & $\mathrm{~A} 2$ & A3 & A4 & $\mathrm{B} 1$ & $\mathrm{~B} 2$ & C.1 & $\mathrm{C} 2$ & $\mathrm{C} 3$ & $\mathrm{C} 4$ & $\mathrm{C} 5$ & C6 & $C 7$ & $\mathrm{C} 8$ \\
\hline $14: 0$ & 1.3 & 5.3 & 0.3 & 0.8 & 0.5 & 0.5 & 1.5 & 0.2 & 1.4 & 1.6 & 1.1 & 0.8 & 0.2 & 0.5 \\
\hline $15: 0$ & 0.3 & 0.3 & 0.1 & 0.2 & 0.1 & 0.1 & 0.3 & 0.0 & 0.2 & 0.1 & 0.1 & 0.1 & 0.0 & 0.1 \\
\hline $16: 0$ & 5.0 & 30.1 & 1.2 & 4.8 & 2.3 & 2.3 & 8.3 & 1.1 & 4.9 & 6.5 & 2.7 & 5.5 & 1.1 & 2.5 \\
\hline $16: 1(n-7)$ & 1.9 & 6.4 & 2.1 & 0.4 & 1.0 & 0.3 & 2.7 & 0.1 & 1.5 & 3.1 & 0.5 & 0.6 & 0.1 & 0.6 \\
\hline $16: 2(n-6)$ & 0.2 & 0.5 & 0.0 & 0.2 & 0.3 & 0.0 & 1.0 & 0.0 & 0.1 & 1.3 & 0.0 & 0.6 & 0.0 & 0.1 \\
\hline $16: 4(n-3)$ & 0.4 & 0.8 & 0.1 & 0.1 & 1.2 & 0.1 & 0.5 & 0.1 & 0.4 & 1.0 & 0.0 & 0.1 & 0.0 & 0.1 \\
\hline $18: 0$ & 11.1 & 14.2 & 12.6 & 6.1 & 14.1 & 1.0 & 22.9 & 3.8 & 3.5 & 3.3 & 4.9 & 43.9 & 5.2 & 5.8 \\
\hline $18: 1(n-9)$ & 7.2 & 22.7 & 1.1 & 10.4 & 1.4 & 0.9 & 11.7 & 0.6 & 7.5 & 6.0 & 2.9 & 3.8 & 0.2 & 2.0 \\
\hline $18: 1(n-7)$ & 0.6 & 15.8 & 0.3 & 0.8 & 0.3 & 0.3 & 4.1 & 0.1 & 1.0 & 4.0 & 0.8 & 0.8 & 0.0 & 0.6 \\
\hline $18: 2(n-6)$ & 0.9 & 4.9 & 0.2 & 2.3 & 0.3 & 0.2 & 2.1 & 0.1 & 1.7 & 1.1 & 1.1 & 0.7 & 0.0 & 0.4 \\
\hline $18: 3(n-3)$ & 0.0 & 2.3 & 0.1 & 0.3 & 0.2 & 0.2 & 0.5 & 0.1 & 0.6 & 0.6 & 1.5 & 0.0 & 0.0 & 0.0 \\
\hline $18: 4(n-3)$ & 0.4 & 4.3 & 0.3 & 0.3 & 1.3 & 0.7 & 1.7 & 0.2 & 0.7 & 3.5 & 8.3 & 0.4 & 0.0 & 0.3 \\
\hline $20: 1(n-9)$ & 1.4 & 6.8 & 1.2 & 0.8 & 1.7 & 1.5 & 2.1 & 0.5 & 1.9 & 1.8 & 11.7 & 1.7 & 0.0 & 0.3 \\
\hline $20: 4(n-6)$ & 0.0 & 1.8 & 0.0 & 0.0 & 0.1 & 0.0 & 0.4 & 0.0 & 0.0 & 0.4 & 0.0 & 0.8 & 0.0 & 0.0 \\
\hline $20: 4(n-3)$ & 0.0 & 0.0 & 0.0 & 0.0 & 0.0 & 0.0 & 0.0 & 0.0 & 0.9 & 0.5 & 0.0 & 0.2 & 0.0 & 0.0 \\
\hline $20: 5(n-3)$ & 4.8 & 66.6 & 1.5 & 2.6 & 7.8 & 1.4 & 11.4 & 0.5 & 4.3 & 1.7 .7 & 4.7 & 2.4 & 0.2 & 2.2 \\
\hline $22: 1(n-11)$ & 0.3 & 7.7 & 0.0 & 0.0 & 0.1 & 0.0 & 0.7 & 0.0 & 0.0 & 0.3 & 0.0 & 0.0 & 0.0 & 0.0 \\
\hline $22: 5(n-3)$ & 0.0 & 1.6 & 0.0 & 0.3 & 0.0 & 0.0 & 0.6 & 0.0 & 0.0 & 0.7 & 0.0 & 0.0 & 0.0 & 0.0 \\
\hline $22.6(n-3)$ & 2.4 & 38.2 & 0.3 & 1.8 & 2.2 & 0.9 & 3.6 & 0.1 & 2.5 & 4.7 & 7.1 & 2.4 & 0.0 & 0.5 \\
\hline Total & 38.0 & 230.2 & 21.2 & 32.0 & 34.7 & 10.4 & 76.1 & 7.4 & 33.0 & 58.0 & 47.3 & 64.8 & 6.9 & 16.2 \\
\hline $20.5(n-3) / 16: 0$ & 1.0 & 2.2 & 1.3 & 0.5 & 3.4 & 0.6 & 1.4 & 0.5 & 0.9 & 2.7 & 1.7 & 0.4 & 0.1 & 0.9 \\
\hline $16: 1(n-9) / 16: 0$ & 0.4 & 0.2 & 1.7 & 0.1 & 0.5 & 0.1 & 0.3 & 0.1 & 0.3 & 0.5 & 0.2 & 0.1 & 0.1 & 0.3 \\
\hline $18: 1(n-7) / 18: 1(n-9)$ & 0.1 & 0.7 & 0.2 & 0.1 & 0.2 & 0.4 & 0.4 & 0.1 & 0.1 & 0.7 & 0.3 & 0.2 & 0.0 & 0.3 \\
\hline
\end{tabular}

tions. The highest biomasses of prymnesiophytes were found at the A stations and of chrysophytes at Stns C4 and C5. Peridinin, the dinoflagellate marker, was only recorded at Stn C5. Large diatoms were scarce and the commonly occurring summer bloom of large diatoms (Priddle et al. 1995) was not observed. The biomass of the $>20 \mu \mathrm{m}$ fraction only exceeded that of the $<20 \mu \mathrm{m}$ fraction at Stns A2 and C3. The $>20 \mu \mathrm{m}$ fraction was exclusively diatoms.

The fatty acids in the phytoplankton were variable (Table 2). The highest total fatty acid concentration corresponded to the highest proportion of PUFAs 20:5(n-3) and 22:6(n-3) at Stn A2. Stns C4 and C5 had the highest concentrations of $18: 4(n-3)$, which corresponded to the highest chrysophyte and dinoflagellate levels (see above). Fatty acid 16:1(n-7), which has been found in many species of diatom (Sargent et al. 1987), exceeded the 16:0 content at Stn A3. The 18:0 was typically variable but was always present in high proportion. There was no correlation between the variation in total fatty acids and the chlorophyll $a$ concentrations. This may have been caused by the presence of different algal species or other suspended particulates such as detritus.

\section{Euphausia superba fatty acids}

Cluster analysis of the fatty acid data set for krill showed that the samples formed 3 clear groups (Fig. 2) which were labelled A, B and C (Fig. 1, Table 3). Krill classified in Group A had high concentration and proportion of $16: 0$, and a mean $16: 1(n-7) / 16: 0$ ratio of 0.4 . Krill in Group C had lower concentrations of 16:0, high proportions of PUFA(n-3) and a mean 16:1(n-7)/16:0 ratio of 1.0. Those in Group B had fatty acid concentrations and proportions which were intermediate between



Fig. 2. Dendrogram of the cluster analysis performed on the fatty acid data for krill from South Georgia, January and February 1996 
Table 3. Concentration of fatty acids in krill from South Georgia, $\mathrm{mg} \mathrm{kg}^{-1}$, wet weight

\begin{tabular}{|c|c|c|c|c|c|c|c|c|c|c|c|c|c|c|}
\hline Stn & $\mathrm{A} 1$ & $\mathrm{~A} 2$ & A3 & A4 & B1 & B2 & $\mathrm{C} 1$ & $\mathrm{C} 2$ & C3 & $\mathrm{C} 4$ & C5 & $\mathrm{C} 6$ & $\mathrm{C7}$ & C8 \\
\hline $14: 0$ & 511.8 & 136.6 & 162.6 & 168.6 & 69.8 & 68.7 & 24.0 & 16.2 & 35.6 & 18.3 & 53.6 & 18.5 & 7.4 & 6.7 \\
\hline $15: 0$ & 13.8 & 0.0 & 4.5 & 7.4 & 2.4 & 1.7 & 0.5 & 0.5 & 0.9 & 2.2 & 2.6 & 0.0 & 0.3 & 0.3 \\
\hline $16: 0$ & 764.9 & 303.8 & 260.4 & 252.6 & 118.8 & 80.6 & 31.4 & 21.0 & 51.6 & 35.6 & 70.7 & 34.6 & 10.9 & 9.6 \\
\hline $16: 1(n-7)$ & 273.5 & 103.2 & 115.8 & 95.7 & 88.3 & 53.1 & 31.8 & 21.7 & 41.5 & 18.0 & 70.1 & 42.9 & 10.2 & 9.9 \\
\hline $16: 2(n-6)$ & 23.4 & 13.4 & 29.4 & 25.5 & 16.1 & 12.0 & 8.4 & 6.5 & 11.5 & 9.1 & 15.2 & 12.1 & 3.9 & 4.3 \\
\hline $16: 4(n-3)$ & 5.3 & 0.0 & 4.4 & 8.6 & 6.5 & 13.7 & 10.6 & 5.1 & 23.2 & 22.3 & 21.5 & 15.5 & 6.8 & 7.9 \\
\hline $18: 0$ & 36.5 & 16.9 & 14.4 & 2.1 & 4.1 & 3.7 & 1.2 & 0.6 & 3.0 & 3.3 & 3.2 & 1.4 & 0.3 & 0.3 \\
\hline $18: 1(n-9)$ & 268.6 & 158.7 & 58.4 & 48.9 & 66.1 & 27.1 & 21.6 & 13.7 & 39.1 & 12.3 & 41.5 & 29.0 & 6.0 & 4.5 \\
\hline $18: 1(n-7)$ & 125.6 & 79.2 & 39.8 & 23.3 & 47.6 & 13.6 & 11.3 & 7.9 & 19.1 & 10.1 & 31.6 & 16.7 & 4.4 & 4.0 \\
\hline $18: 2(n-6)$ & 51.5 & 20.1 & 15.1 & 20.2 & 17.6 & 6.8 & 6.3 & 4.9 & 12.2 & 6.0 & 37.4 & 13.6 & 4.8 & 4.4 \\
\hline $18: 3(n-3)$ & 12.9 & 2.8 & 3.8 & 8.5 & 1.7 & 3.6 & 2.3 & 5.4 & 5.8 & 3.1 & 26.5 & 3.0 & 3.4 & 2.9 \\
\hline $18: 4(n-3)$ & 23.3 & 6.3 & 8.8 & 26.6 & 15.2 & 18.3 & 13.3 & 17.5 & 34.5 & 34.4 & 84.5 & 28.7 & 19.1 & 14.2 \\
\hline $20: 1(n-9)$ & 14.3 & 2.9 & 5.7 & 9.2 & 2.4 & 1.6 & 1.2 & 0.3 & 4.4 & 3.6 & 0.0 & 2.0 & 0.4 & 0.0 \\
\hline $20: 4(n-6)$ & 5.5 & 0.0 & 1.9 & 2.7 & 2.1 & 1.1 & 0.7 & 0.8 & 1.7 & 0.0 & 8.1 & 2.2 & 0.7 & 1.0 \\
\hline $20: 4(n-3)$ & 5.5 & 0.0 & 3.1 & 0.0 & 1.9 & 0.5 & 0.8 & 1.2 & 2.0 & 2.2 & 14.5 & 4.5 & 1.9 & 1.6 \\
\hline $20: 5(n-3)$ & 128.1 & 53.5 & 67.0 & 95.3 & 89.8 & 85.0 & 65.1 & 54.4 & 150.9 & 112.8 & 259.2 & 175.7 & 80.3 & 74.9 \\
\hline $22: 1(n-11)$ & 4.2 & 0.0 & 3.0 & 1.5 & 0.0 & 0.0 & 0.4 & 0.0 & 0.0 & 7.2 & 0.0 & 2.3 & 0.0 & 0.0 \\
\hline $22: 5(n-3)$ & 0.0 & 0.0 & 0.5 & 0.8 & 0.7 & 0.6 & 0.5 & 0.0 & 1.2 & 0.0 & 3.4 & 1.3 & 0.7 & 0.5 \\
\hline $22: 6(n-3)$ & 13.7 & 6.3 & 8.8 & 16.9 & 10.5 & 8.8 & 5.6 & 5.8 & 15.6 & 14.1 & 39.1 & 20.4 & 12.4 & 11.2 \\
\hline Total & 2282.4 & 903.9 & 807.4 & 814.5 & 561.7 & 400.4 & 237.0 & 183.6 & 453.9 & 314.6 & 782.8 & 424.4 & 173.8 & 158.2 \\
\hline $20: 5(n-3) / 16: 0$ & 0.2 & 0.2 & 0.3 & 0.4 & 0.8 & 1.1 & 2.1 & 2.6 & 2.9 & 3.2 & 3.7 & 5.1 & 7.4 & 7.8 \\
\hline $16: 1(n-7) / 16: 0$ & 0.4 & 0.3 & 0.4 & 0.4 & 0.7 & 0.7 & 1.0 & 1.0 & 0.8 & 0.5 & 1.0 & 1.2 & 0.9 & 1.0 \\
\hline $18: 1(n-7) / 18: 1(n-9)$ & 0.5 & 0.5 & 0.7 & 0.5 & 0.7 & 0.5 & 0.5 & 0.6 & 0.5 & 0.8 & 0.8 & 0.6 & 0.7 & 0.9 \\
\hline
\end{tabular}

Groups $A$ and $C$ with a mean $16: 1(n-7) / 16: 0$ ratio of 0.7 . The relationship between the 20:5(n-3) and 16:0 fatty acid concentrations strongly influenced the cluster analysis and was directly related to the group classification (Fig. 3). The ratio of $20: 5(\mathrm{n}-3)$ to $16: 0$ gave values of 0.2 to 0.5 for Group A, 0.8 to 1.1 for Group $\mathrm{B}$ and 2.0 to 7.5 for Group C (Table 3 ). The stations were numbered according to the sequence of this ratio.

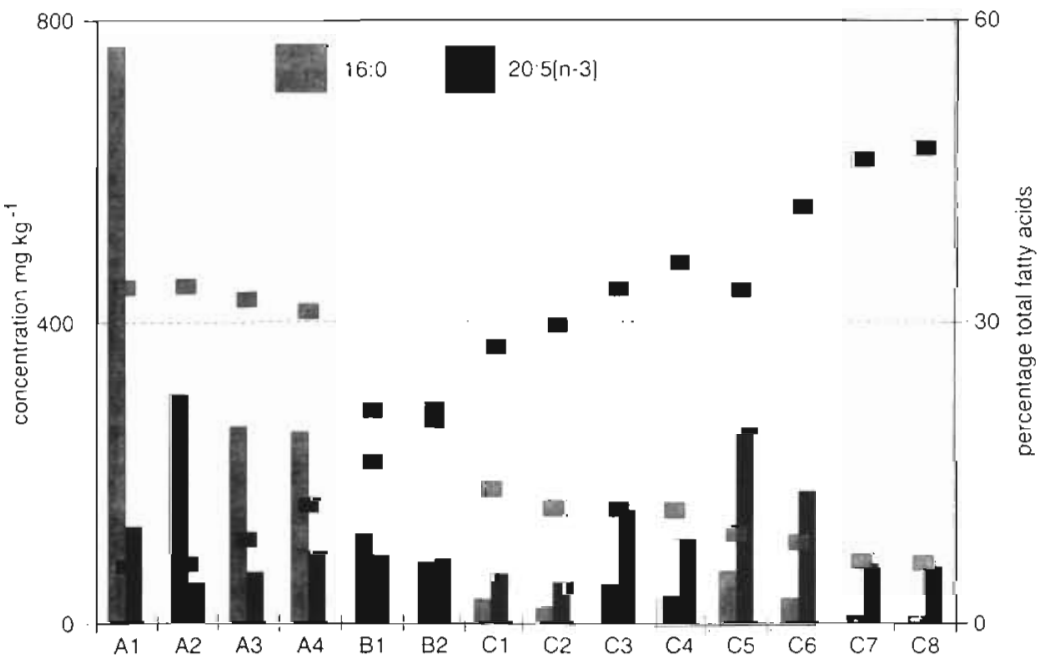

Fig. 3. Comparison of the 16:0 and 20:5(n-3) fatty acid content of krill at South Georgia, January and February 1996, as concentration (bars) and percentage (squares)
The total fatty acids concentration in krill varied from $158 \mathrm{mg} \mathrm{kg}^{-1}$ at Stn C8 to $2282 \mathrm{mg} \mathrm{kg}^{-1}$ (wet mass) at Stn A1 (Table 3). The highest total concentrations corresponded to the highest levels of the saturated fatty acids 14:0,16:0 and 18:0 at Group A stations. The variation in the concentrations of the PUFAs 16:4(n-3), $18: 4(\mathrm{n}-3), 20: 5(\mathrm{n}-3)$ and $22: 6(\mathrm{n}-3)$ was generally small, with the highest levels at Stns C3, C4, C5 and C6.

However, there was greater variation in the percentage content of these PUFAs. The 20:5(n-3) data (and data for other PUFA) expressed as percentage of the total fatty acids showed a distinct trend between stations (Fig. 3) in an inverse relationship to the $16: 0$ percentage. The 18:1(n-7)/18:1(n-9) ratio exhibited no particular trend and varied between 0.5 and 0.8 .

The fatty acid patterns of krill from the Bellingshausen Sea could be divided into 2 groups: (1) adult males and sub-adult males and (2) juveniles, subadult females, and adult females. Males had the highest proportion of PUFAs compared to juveniles and females, which had higher levels of 16:0 (Table 4). The krill from Groups A and $B$ at South Georgia had similar fatty acid patterns to the population as 
Table 4. Concentration of fatty acids in krill from the Bellingshausen Sea classified by maturity and sex, and for the population as a whole, $\mathrm{mg} \mathrm{kg}^{-1}$, wet weight

\begin{tabular}{|c|c|c|c|c|c|c|}
\hline & Juvenile & $\begin{array}{l}\text { Sub-adult } \\
\text { female }\end{array}$ & $\begin{array}{c}\text { Adult } \\
\text { female }\end{array}$ & $\begin{array}{l}\text { Sub-adult } \\
\text { male }\end{array}$ & $\begin{array}{l}\text { Adult } \\
\text { male }\end{array}$ & $\begin{array}{l}\text { Whole } \\
\text { population }\end{array}$ \\
\hline $14: 0$ & 530.6 & 281.6 & 350.8 & 95.2 & 189.4 & 409.9 \\
\hline $15: 0$ & 15.7 & 9.3 & 10.4 & 2.7 & 5.2 & 11.0 \\
\hline $16: 0$ & 959.3 & 558.9 & 806.1 & 468.0 & 304.5 & 896.3 \\
\hline $16: 1(n-7)$ & 347.1 & 176.5 & 268.5 & 133.4 & 139.1 & 229.6 \\
\hline $16: 2(n-6)$ & 63.7 & 35.0 & 51.8 & 44.6 & 22.2 & 46.7 \\
\hline $16: 4(n-3)$ & 5.4 & 5.7 & 7.4 & 8.6 & 21.5 & 21.6 \\
\hline $18: 0$ & 56.7 & 37.1 & 42.7 & 119.7 & 13.8 & 56.1 \\
\hline $18: 1(n-9)$ & 392.8 & 226.6 & 346.4 & 643.1 & 160.5 & 328.4 \\
\hline $18: 1(n-7)$ & 260.9 & 148.4 & 216.7 & 321.6 & 128.6 & 196.9 \\
\hline $18: 2(n-6)$ & 86.1 & 43.5 & 51.2 & 78.9 & 51.9 & 47.2 \\
\hline $18: 3(n-3)$ & 24.9 & 12.3 & 17.9 & 37.5 & 19.8 & 18.2 \\
\hline $18: 4(n-3)$ & 49.6 & 27.6 & 44.4 & 128.0 & 70.4 & 79.4 \\
\hline $20: 1(n-9)$ & 24.3 & 12.9 & 18.0 & 69.5 & 3.8 & 17.4 \\
\hline $20: 4(n-6)$ & 12.3 & 7.7 & 9.7 & 276.0 & 14.3 & 8.9 \\
\hline $20: 4(n-3)$ & 9.1 & 5.8 & 7.3 & 35.4 & 8.8 & 10.3 \\
\hline $20: 5(n-3)$ & 130.1 & 90.1 & 170.9 & 842.3 & 286.9 & 269.6 \\
\hline $22: 1(n-11)$ & 7.7 & 6.0 & 3.5 & 44.0 & 6.9 & 9.5 \\
\hline $22: 5(n-3)$ & 4.4 & 0.0 & 4.2 & 22.8 & 6.8 & 4.4 \\
\hline $22: 6(n-3)$ & 67.1 & 54.7 & 87.8 & 581.2 & 174.0 & 128.7 \\
\hline Total & 3047.8 & 1739.9 & 2515.8 & 3952.5 & 1628.4 & 2789.8 \\
\hline $20: 5(n-3) / 16: 0$ & 0.1 & 0.2 & 0.2 & 1.8 & 0.9 & 0.3 \\
\hline $16: 1(n-7) / 16: 0$ & 0.4 & 0.5 & 0.6 & 6.3 & 2.1 & 1.2 \\
\hline $18: 1(n-7) / 18: 1(n-9)$ & 0.3 & 0.3 & 0.2 & 0.2 & 0.4 & 0.2 \\
\hline
\end{tabular}

ately south of the Polar Front (Brandon et al. 1999). Stns A1 and A3 were spatially close, but were sampled a month apart, implying that the same krill were present in the same location even though the krill and water would have been moving. This may have been due to an oceanographic 'doldrum' or a group of krill that originated further to the south which was moving northwards towards the Maurice Ewing Bank. The Group B stations were in a region where a strong current from the south meets the slower westerly current flowing parallel to the north coast of South Georgia (Brandon unpubl.). Krill at Stns B1 and B2 appeared to be an intermediate group; a combination of juvenile animals from Group $\mathrm{C}$ and adults from another region probably to the southwest. Most of the C stations were on the shelf, and the strong flow of Weddell Sea water from the east may have contributed to the mixing of groups of krill to the northwest of the Island. This would also explain the geographical proximity of Stn C6 to Stns A1 and A3.

a whole from the Bellingshausen Sea, but all concentrations from South Georgia were lower, with the exception of Stn A1 (Table 3).
Principal Components Analysis (PCA) when applied to the data set which combined the results for fatty acids in phytoplankton from South Georgia, krill from South Georgia and krill from the Bellingshausen Sea

\section{Cluster and Principal Components Analysis of fatty acid data}

The 3 groups classified by cluster analysis of the fatty acid data corresponded to 3 groups of krill as defined by their size, sex, maturity and geographical distribution (Fig. 1, Table 5, Watkins et al. in press). Group A consisted primarily of sub-adults (median length $42 \mathrm{~mm}$ ), Group B comprised mainly juveniles and a small proportion of adults (median length $33 \mathrm{~mm}$ ) and Group $C$ was almost exclusively juveniles with a few sub-adults (median length $29 \mathrm{~mm}$ ). Group A stations were split geographically (Fig, 1) but had similar fatty acid profiles, length frequencies and development stages. Either these were similar, but separate groups of krill, or they were 1 group which inhabited the waters immedi-
Table 5. Maturity, sex and length frequency of krill sampled ( $\mathrm{n}=100$ for each sample). SD: standard deviation; Juv: juvenile; FS: female sub-adult; MS: male sub-adult; FA: female adult; MA: male adult

\begin{tabular}{|cccccccccc|}
\hline \multirow{2}{*}{ Stn } & \multirow{2}{*}{ Date (1996) } & \multicolumn{3}{c}{ Length (mm) } & \multicolumn{4}{c|}{ Age and sex (\%) } \\
& & Mean & Median & SD & Juv & FS & MS & FA & MA \\
\hline A1 & 20 Feb & 43.3 & 43 & 3.1 & 3 & 46 & 50 & 1 & 0 \\
A2 & 14 Feb & 39.5 & 42 & 3.7 & 39 & 29 & 59 & 0 & 0 \\
A3 & 28 Jan & - & - & - & - & - & - & - & - \\
A4 & 13 Feb & 41.9 & 40 & 4.2 & 11 & 32 & 55 & 2 & 0 \\
& & & & & & & & & \\
B1 & 21 Jan & 34.9 & 32 & 9.1 & 69 & 0 & 14 & 9 & 8 \\
B2 & 26 Jan & 37.8 & 34 & 10.6 & 51 & 9 & 9 & 15 & 16 \\
& & & & & & & & & \\
C1 & 18 Jan & 30.6 & 29 & 5.1 & 84 & 9 & 7 & 0 & 0 \\
C2 & 14 Jan & 29.8 & 26 & 8.6 & 73 & 2 & 18 & 7 & 2 \\
C3 & 24 Jan & 32.5 & 32 & 5.6 & 74 & 2 & 23 & 0 & 1 \\
C4 & 18 Jan & 25.7 & 25 & 2.6 & 98 & 1 & 1 & 0 & 0 \\
C5 & 22 Feb & 27.3 & 27 & 2.8 & 99 & 0 & 1 & 0 & 0 \\
C6 & 29 Jan & 34.9 & 34 & 4.8 & 64 & 8 & 27 & 0 & 1 \\
C7 & 14 Jan & 29.4 & 29 & 3.2 & 92 & 1 & 7 & 0 & 0 \\
C8 & 13 Feb & 29.4 & 28 & 4.6 & 96 & 0 & 4 & 0 & 0 \\
& & & & & & & & & \\
\hline
\end{tabular}


Table 6. Principal component coefficients for the fatty acid data set for phytoplankton at South Georgia, krill from South Georgia and krill from Bellingshausen Sea (the most important components are highlighted in bold type)

\begin{tabular}{|lccc|}
\hline $\begin{array}{l}\text { Proportion } \\
\text { of variance }\end{array}$ & PC1 & PC2 & PC3 \\
\hline Fatty acid & $34 \%$ & $20 \%$ & $19 \%$ \\
$14: 0$ & & & \\
$15: 0$ & -0.185 & -0.057 & $+\mathbf{0 . 4 3 9}$ \\
$16: 0$ & -0.175 & -0.018 & $+\mathbf{0 . 3 2 7}$ \\
$16: 1(n-9)$ & -0.223 & -0.214 & $+\mathbf{0 . 3 5 6}$ \\
$16: 2(n-6)$ & -0.145 & -0.276 & +0.142 \\
$16: 4(n-3)$ & -0.240 & +0.230 & +0.264 \\
$18: 0$ & -0.178 & $+\mathbf{0 . 3 8 4}$ & -0.029 \\
$18: 1(n-9)$ & +0.135 & -0.188 & -0.195 \\
$18: 1(n-7)$ & -0.257 & $-\mathbf{0 . 3 0 4}$ & +0.090 \\
$18: 2(n-6)$ & $-\mathbf{0 . 3 1 4}$ & -0.253 & +0.086 \\
$18: 3(n-3)$ & -0.356 & +0.048 & +0.029 \\
$18: 4(n-3)$ & -0.282 & +0.210 & -0.119 \\
$20: 1(n-9)$ & -0.229 & $+\mathbf{0 . 3 6 4}$ & -0.124 \\
$20: 4(n-6)$ & -0.017 & -0.178 & -0.262 \\
$20: 4(n-3)$ & -0.145 & -0.112 & -0.169 \\
$20: 5(n-3)$ & -0.190 & +0.319 & -0.070 \\
$22: 1(n-11)$ & $-\mathbf{0 . 3 0 9}$ & +0.181 & -0.211 \\
$22: 5(n-3)$ & -0.223 & -0.239 & -0.250 \\
$22: 6(n-3)$ & -0.255 & -0.165 & -0.297 \\
& -0.258 & -0.200 & -0.320 \\
\hline
\end{tabular}

accounted for $73 \%$ of the variance in the data with the first 3 principal components (Table 6). The first principal component (PC1) showed that nearly all the fatty acids were variables of similar importance, with $18: 1(n-7), 18: 2(n-6)$, and $20: 5(n-3)$ having the coefficients with the highest magnitude. The second principal component (PC2) identified the 16:4(n-3), 18:1(n-9)

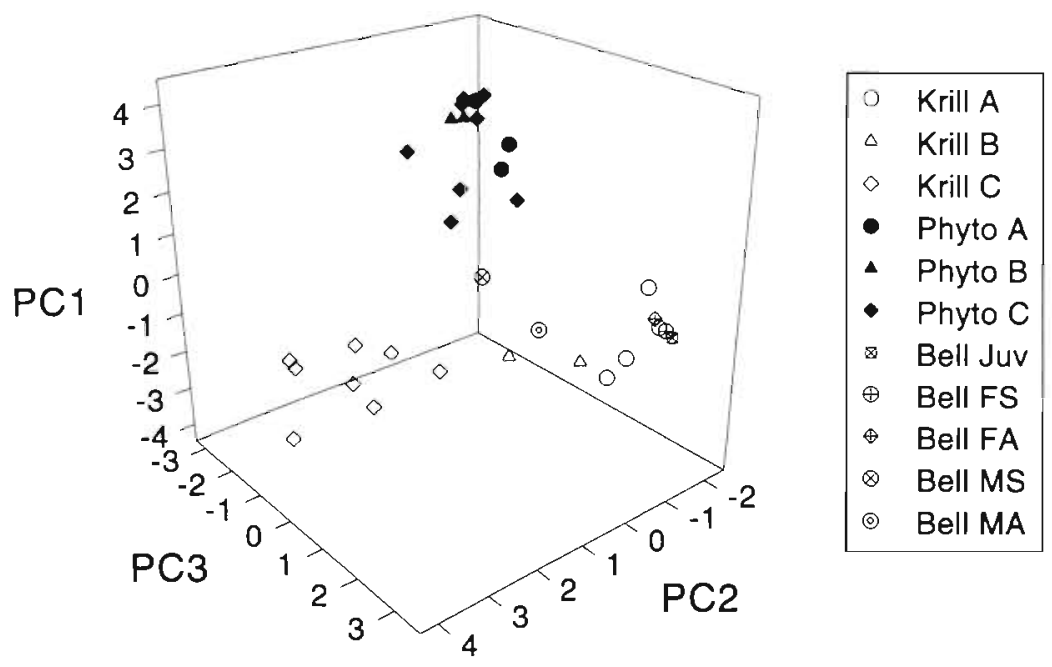

Fig. 4. Plot of the scores of the first 3 principal components ( $\mathrm{PC} 1$ to 3 ) on the data set which combined the results for fatty acids in phytoplankton from South Georgia, krill from South Georgia and krill from the Bellingshausen Sea (see Table 5 for codes). One outlier point was not plotted for phytoplankton at Stn A2, which had the co-ordinates $-5.5,-6.5,-4.5$ and 20:4(n-3) compounds as the most important and the third principal component (PC3) found the 14:0, $15: 0,16: 0$ and $22: 6(n-3)$ fatty acids were the most significant components. The calculated scores of the first 3 components for each sample are plotted in Fig. 4, which highlights the difference in loading between phytoplankton and the krill groups A and C. PC1 identified the fatty acids in phytoplankton to be distinct from all krill samples. PC1 was not able to separate the krill groups but PC2 and PC3 split the krill into groups, as with the cluster analysis (see above). In comparison to Group A, PC2 showed the fatty acid content of krill from Group $C$ to be remote to the fatty acids in phytoplankton. Group A had similar fatty acids to those of phytoplankton and the krill from the Bellingshausen Sea. PC3 classified the adult female, sub-adult female and juvenile krill from the Bellingshausen Sea with the $A$ and B krill groups from South Georgia and the adult and sub-adult male krill with Group $C$ from South Georgia.

\section{DISCUSSION}

\section{Effect of maturity and sex on the fatty acids of krill}

Earlier work has reported that total lipid content has been shown to vary with maturity and sex in krill (Clarke 1980), and that juveniles contain more lipid than mature krill (Clarke 1984). Thus, total fatty acids might be expected to vary in this way as well. However, juvenile krill from the Bellingshausen Sea had total fatty acid concentrations that were lower than in male sub-adults but higher than in sub-adult females, adult females and adult males (Table 4). Virtue et al. (1996) and Clarke (1980) also found krill males to have a higher percentage of PUFAs than females or juveniles, which is supported by our results from the Bellingshausen Sea. Hence, any dietary signal in the fatty acids may become obscured in a krill population dominated by adult males. At the A stations there was a high proportion of male sub-adults and the PUFA concentrations were similar to those of krill from the $B$ and $C$ stations, but the percentage PUFA content was lower. The almost exclusively juvenile population of Group $\mathrm{C}$ had high proportions of PUFA compared to krill from the Bellingshausen Sea. Evidence suggests that there were other influences affecting the pattern and content of fatty acids in krill. 


\section{Reflection of diet in fatty acids of krill}

Omnivory

The fatty acid profile of many species of zooplankton has been shown to reflect their diet. Thus, as the fatty acid profiles of krill from the $A$ and $B$ stations were similar to those from the Bellingshausen Sea, it could be inferred that they also had a similar diet (Tables $3 \&$ 4). In the Bellingshausen Sea, krill were sampled during a diatom bloom (Boyd et al. 1995) and their fatty acid profiles indicated that algae were a major constituent of their diet. In contrast, krill from the easternmost stations at South Georgia, Stns C1, $\mathrm{C} 2, \mathrm{C} 7$ and $\mathrm{C} 8$, were living in waters with a low algal biomass and had low concentrations of fatty acids. The fatty acid profile of krill in Group C was radically different to the krill from Groups $A$ and $B$ and from the Bellingshausen Sea, implying a different diet. A comparison of juveniles from the Bellingshausen Sea with krill from C stations at South Georgia not only revealed different patterns of fatty acids but also a large disparity in concentrations (Fig. 5). PCA indicated that krill from all the $C$ stations had similar recent dietary histories, which included those exposed to the highest potential food levels at Stns C4 and C5. However, there appeared to be no relation between Group C krill and the phytoplankton available (Fig. 4).

It has been reported that krill have a general preference for larger food (>20 $\mu \mathrm{m}$ ) (Ishii et al, 1985, Quetin \& Ross 1985, Atkinson \& Snÿder 1997. Opalinski et al. 1997, Cripps unpubl. obs.). This could partially explain the apparent lack of accumulation of lipids in Group C, due to a reluctance to ingest or inability to digest small phytoplankton. Stns C3 and C5 were spatially close (Fig. 1) but temporally separated by $4 \mathrm{wk}$. The composition of phytoplankton in the water column did not change over this period (comprising mainly small diatoms and chrysophytes) but the total algal biomass had increased from 1600 to $5200 \mathrm{ng} \mathrm{l}^{-1}$ (as chlorophyll a). The total fatty acid concentration in krill at these stations had only increased from 425 to $722 \mathrm{mg} \mathrm{kg}^{-1}$ and the pattern of fatty acids remained the same. Thus, even in the presence of a high biomass, there appeared to be a reluctance to feed on small algae.

The phytoplankton biomass available to zooplankton during the study was lower than average for summer at South Georgia, which indicated a poor production year or that the algal community had already passed through its period of maximum growth. Some studies have shown that high krill populations and high phytoplankton populations are spatially mutually exclusive (e.g. Weber \& El-Sayed 1985). The phytoplankton, particularly at the $\mathrm{C}$ stations, may have been grazed heavily by a relatively large biomass of macro-zooplankton
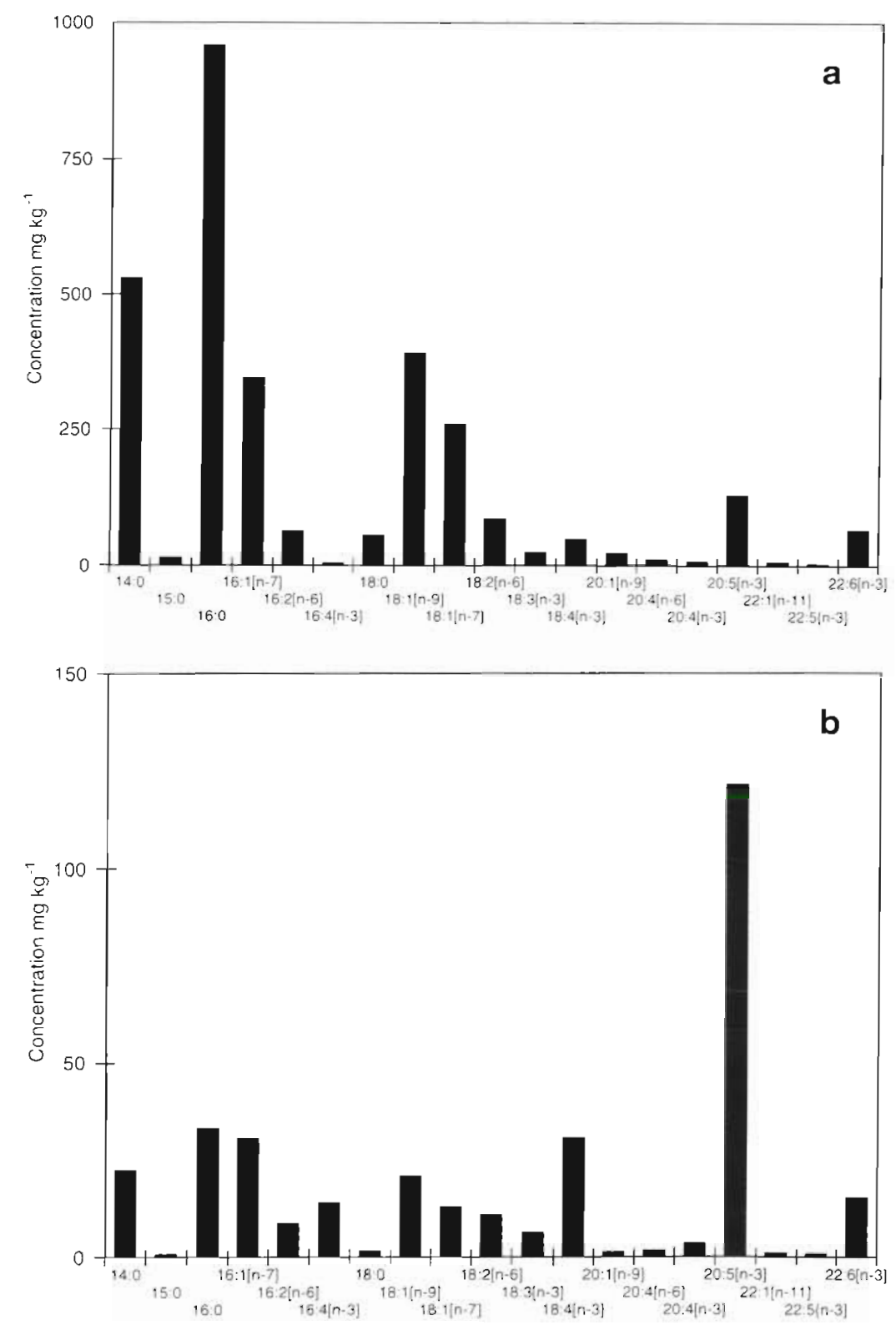

Fig. 5. Comparison of the fatty acid concentration patterns for (a) juvenile krill from the Bellingshausen Sea and (b) those from Group C. South Georgia 
(Watkins et al. in press). If the phytoplankton had been grazed heavily, the fatty acids of krill in Group $C$ would have included components of the diet or the pattern would have been similar to the well fed krill from the Bellingshausen Sea. The essentially juvenile population at the $\mathrm{C}$ stations might have catabolised dietaryimportant fatty acids rapidly for development rather than accumulate them. The juvenile krill from the Bellingshausen Sea had greater fatty acid concentrations and exhibited a fatty acid profile resembling those previously reported and showed no evidence of accumulating PUFAs.

The quality of the available diet was reflected in the algal fatty acids; for example, the general low abundance of diatoms as indicated by the small proportion of the $16: 1(n-7)$ fatty acid. The proportion of 18:0 was generally high for Antarctic phytoplankton compared to previous reports (Nichols et al. 1989, 1991, Pond et al. 1993, Virtue et al. 1993, Skerratt et al. 1995) and standard algal cultures (Volkman et al. 1989, Viso \& Marty 1993). A high 18:0 content has also been found in krill faeces (Cripps unpubl. data) and sedimenting material from the Southern Ocean (Tanoue 1985, Hayakawa et al. 1996). However, the moderate percentages of the essential dietary PUFA such as 20:5(n-3) indicated that the phytoplankton was nutritionally useful, even if only present in low biomass.

\section{Starvation or carnivory}

In the absence of a spring bloom, krill may have resorted to alternate survival strategies, such as dietary change or body shrinkage (see Nicol et al. 1992). The pattern of fatty acids in the krill from Groups A and B was similar to those from the Bellingshausen Sea; hence, it was assumed that Group A and B krill were not starving or did not have a recent history of starvation. The fatty acid profile of Group $\mathrm{C}$ was substantially different from that of well fed krill, so starvation and dietary change must be considered. Membrane lipids are high in PUFAs, and catabolism under dietary stress could release PUFAs as a result of body shrinkage, for example. Experiments by Virtue et al. $(1993,1997)$ found that total lipid concentration decreased with starvation but that little change occurred in the fatty acid pattern over a period of $115 \mathrm{~d}$.

Morris \& Sargent (1973) proposed that some oceanic crustaceans could synthesize higher PUFAs such as $20: 5(n-3)$ and $22: 6(n-3)$. This would be achieved by a combination of chain elongation and desaturation of, for example, 16:1 and 18:1 fatty acids. If saturated and monounsaturated fatty acids were catabolised in starving krill, this would have resulted in the lower levels of $16: 0,16: 1(n-7), 18: 0$ and $18: 1(n-9)$, as observed for the
C stations (Table 2), and an increased proportion of PUFAs. As yet there is no evidence that krill produce 18:4(n-3), 20:5(n-3) and 22:6(n-3) from lower saturated and monounsaturated fatty acids. When krill are feeding herbivorously their diet will be rich in PUFAs so there is no requirement for biosynthesis. The variation in PUFA concentrations throughout the $\mathrm{C}$ group suggest that krill were feeding on other zooplankton or small phytoplankton, but this was probably sporadic or at low rates. In poor feeding conditions lipids ingested may be used up quickly as opposed to good feeding conditions when lipids can be stored.

Huntley et al. (1994) suggest that if krill stop feeding, or feed at very low rates during the winter, they reduce their metabolism, utilise lipid stores and may shrink in size. This might also be the case during the summer in areas of general low algal biomass, such as in the east of our study area (C stations). Alternatively, carnivory may enable krill to survive and sustain growth during periods of low algal availability. Certainly it would be strategically important for the largely juvenile population from the $\mathrm{C}$ stations to maintain input for growth and stores in the latter half of the summer. Thus, the low algal biomass which had been persistent for a number of weeks probably led krill into an extended period of carnivory. During the same cruise, shipboard experiments and in situ gut fluorescence measurements showed that algae were a minor source of carbon uptake (algal carbon ration was $\sim 0.7 \%$ of krill carbon $\mathrm{d}^{-1}$ ) and that protozoans and copepods supplied most of their carbon intake (Atkinson \& Snÿder 1997). Experiments have shown that krill can ingest a range of copepods: Calanus simillimus, Drepanopus forcipatus, Euchaeta antarctica, Metridia gerlachei, Oithona spp. and Rhincalanus gigas (Price et al, 1988, Atkinson \& Snÿder 1997). Antarctic calanoid copepods such as $R$. gigas, Calanoides acutus, Calanus propinquus and those above can accumulate high proportions of dietary fatty acids (PUFAs) (Graeve et al. 1994b, Kattner et al. 1994, Ward et al. 1996, Cripps \& Hill 1998) and, thus, could provide a rich source of these compounds. High levels of $16: 1(n-7)$ in E. antarctica, R. gigas and C. acutus would make these species a more likely dietary item at the $\mathrm{C}$ stations than at the A stations.

Atkinson et al. (1999) show that the density of copepods is generally lower over the area of the C stations than at the $A$ and $B$ stations. The most numerous copepod present was the small cyclopoid Oithona spp. but analysis of Oithona spp. (Cripps \& Hill 1998) has shown them to be rich in 18:1(n-9), 20:1(n-9) and $22: 1(n-11)$. The low proportion of the latter 2 fatty acids in the krill at any of the stations does not support Oithona spp. as a dietary item. If the high concentrations of $20: 5(n-3)$ and relatively high proportions of $16: 1(n-7)$ in krill from the $C$ stations were the result of 
carnivory, then Rhincalanus gigas and Calanoides acutus may also have been components of the diet.

It is an open question whether krill can actively hunt motile species which may have well developed escape responses over short distances. The morphology of the feeding basket allows krill to trap efficiently a wide range of items from $5 \mu \mathrm{m}$ to $5 \mathrm{~mm}$ in length (Meyer \& ElSayed 1983, Quetin \& Ross 1991, Pilditch \& McClatchie 1994, Atkinson \& Snÿder 1997); this would comprise the majority of copepods including Rhincalanus gigas and Calanoides acutus. Atkinson \& Snÿder (1997) found that krill would clear 1 to $3 \mathrm{~mm}$ copepods at the fastest rates; $C V$ and CVI $R$. gigas copepodites were not eaten, possibly because of stronger escape responses. There must be a high degree of opportunism to krill feeding carnivorously or scavenging. Krill will feed on larger items of immobile material (dead tissue) in the laboratory (Cripps pers. obs.).

It has been possible to identify regional groups of krill by their fatty acid signatures using statistical routines to deconvolute data and separate seemingly closely related groups, such as A and B. Although there was a high density of copepods and protozoans available at the $A$ and $B$ stations, the krill were mainly herbivorous. It was clear that herbivory was less prevalent in Group C. At the $\mathrm{C}$ stations there was generally a low algal biomass and we suggest that krill had resorted to opportunistic carnivory by consuming zooplankton which were rich in PUFAs. Even in the presence of relatively high densities of flagellates and small diatoms, krill did not incorporate fatty acids characteristic of these algae. The distribution of large diatoms was patchy and restricted to the west of the study area. However, there was sufficient ration for krill in Groups A and B to maintain fatty acid profiles, though not concentrations, comparable to the krill feeding on a diatom bloom. The phytoplankton from the east of the study area had not been recently grazed out and krill had been surviving on a meagre ration for several weeks, supplemented by opportunistic carnivory. Consequently, krill had low concentrations and an unusual pattern of fatty acids. This is evidence for the durability and adaptability of krill which have to survive on a low algal biomass or more carnivorous diets in summer as well as in winter.

Acknowledgements. The authors would like to thank the crew and officers of the RRS 'James Clark Ross' for their expertise and assistance at sea, Julian Priddle and 4 anonymous referees for their advice on the manuscript.

\section{LITERATURE CITED}

Atkinson A, Sn.̈̈der R (1997) Krill-copepod interactions at South Georgia, Antarctica, I. Omnivory by Euphausia superba. Mar Ecol Prog Ser 160:63-76
Atkinson A, Ward P, Hill A, Brierley AS, Cripps GC (1999) Krill-copepod interactions at South Georgia, Antarctica, II. Euphausia superba as a major control on copepod abundance. Mar Ecol Prog Ser 176:63-79

Bottino NR (1975) Lipid composition of the two species of Antarctic krill: Euphausia superba and E. crystallorophias. Comp Biochem Physiol 50B:479-484

Boyd P, Robinson C, Savidge GJ, Williams PJLeB (1995) Water column and sea-ice primary production during austral spring in the Bellingshausen Sea. Deep-Sea Res II 42:1179-1200

Brandon MA, Murphy EJ, Whitehouse MJ, Trathan PN, Murray AWA, Bone DG. Priddle $J(1999)$ The shelf break front to the east of the sub-Antarctic island of South Georgia. Cont Shelf Res 19:799-819

Brierley AS, Watkins JL, Murray AWA (1997) Interannual variability in krill abundance at South Georgia. Mar Ecol Prog Ser 150:87-98

Christie WW (1982) Lipid analysis. Pergamon Press, Oxford

Clarke A (1980) The biochemical composition of krill Euphausia superba Dana, from South Georgia. J Exp Mar Biol Ecol 43:221-236

Clarke A (1984) Lipid content and composition of Antarctic krill, Euphausia superba Dana. J Crust Biol 4(Spec. No. 1): $285-294$

Clarke A, Leakey RJG (1996) The seasonal cycle of phytoplankton, macronutrients and the microbial community in a near-shore Antarctic marine ecosystem. Limnol Oceanogr 41:1281-1294

Cripps GC, Hill HJ (1998) Changes in lipid composition of copepods and Euphausia superba associated with diet and environmental conditions at the marginal ice zone. DeepSea Res I 45:1357-1381

Cripps GC, Iarling GA (1997) Rapid procedure for the isolation and analysis of fatty acid and fatty alcohol fractions from wax esters of marine zooplankton. J Chromatogr A $760: 309-313$

El-Sayed SZ (1985) Plankton of the Antarctic Seas. In: Bonner WN, Walton DWH (eds) Key environments-Antarctica. Pergamon Press, Oxford, p 135-155

Graeve M, Kattner G, Hagen W (1994a) Diet induced changes in the fatty acid composition of Arctic herbivorous copepods: experimental evidence of trophic markers. J Exp Mar Biol Ecol. 182:97-110

Graeve M, Hagen W, Kattner G (1994b) Herbivorous or omnivorous? On the significance of lipid compositions as trophic markers in Antarctic copepods. Deep-Sea Res I 41 : 915-924

Hagen W, Van Vleet ES, Kattner G (1996) Seasonal lipid storage as overwintering strategy of Antarctic krill. Mar Ecol Prog Ser 134:85-89

Hardy AC (1967) Great waters. Collins, London

Hayakawa K, Handa N, Ikuta N, Fukuchi M (1996) Downward fluxes of fatty acids and hydrocarbons during a phytoplankton bloom in the Austral summer in Breid Bay, Antarctica. Org Geochem 24:511-521

Hopkins TL, Ainley DG, Torres JJ, Lancraft TM (1993) Trophic structure in open waters of the marginal ice-zone in the Scotia-Weddell confluence region during spring 1983 Polar Biol 13:389-397

Huntley ME, Nordhausen W, Lopez MDG (1994) Elemental composition, metabolic activity and growth of Antarctic krill Euphausia superba during winter. Mar Ecol Prog Ser $107: 23-40$

Ikeda T, Dixon TI (1982) Body shrinkage as a possible overwintering mechanism of the Antarctic krill, Euphausia superba dana. J Exp Mar Biol Ecol 62:143-151 
Ishii H, Omori M, Murano M (1985) Feeding behaviour of the Antarctic krill Euphausia superba Dana I. Reaction to size and concentration of food particles. Trans Tokyo Univ Fish 6:117-124

Kattner G, Graeve M, Hagen W (1994) Ontogenetic and seasonal changes in lipid and fatty acid/alcohol compositions of the dominant Antarctic copepods Calanus propinquus, Calanoides acutus and Rhincalanus gigas. Mar Biol 118: $637-644$

Laws RM (1985) The ecology of the Southern Ocean. Am Sci 73:26-40

Letelier RM, Bidigare RR, Hebel DV, Ondrusek M, Winn CD, Karl DM (1993) Temporal variability of phytoplankton community structure based on pigment analysis. Limnol Oceanogr 38:1420-1437

Mantoura RFC, Llewellyn CA (1983) The rapid determination of algal chlorophyll and carotenoid pigments and their breakdown products in natural waters by reverse phase high performance liquid chromatography. Anal Chim Acta 151:297-314

Marchant HJ, Murphy EJ (1994) Interactions at the base of the Antarctic food web. In: El-Sayed SZ (ed) Southern Ocean ecology, the biomass perspective. Cambridge University Pres5, Cambridge, p 267-286

Mayzaud P (1997) Spatial and life cycle changes in lipid and fatty acid structure of the Antarctic euphausiid Euphausia superba. In: Battaglia B, Valencia J, Walton DWH (eds) Antarctic communities: species, structure and survival. Cambridge University Press، Cambridge, p 284-294

Mayzaud P, Albessard E, Cuzin-Roudy J (1998) Changes in lipid composition of the Antarctic krill Euphausia superba in the Indian sector of the Antarctic Ocean: influence of geographical location, sexual maturity stage and distribution among organs. Mar Ecol Prog Ser 173:149-162

Meyer MA, El-Sayed SZ (1983) Grazing of Euphausia superba dana on natural phytoplankton populations. Polar Biol 1:193-197

Minitab Inc (1994) Minitab ${ }^{\otimes}$ release 10 for Windows ${ }^{\text {TM }}$. State College, PA

Morris DJ, Watkins JL, Ricketts C, Buchholz F, Priddle J (1988) An assessment of the merits of length and weight measurements of Antarctic krill Euphausia superba. $\mathrm{Br}$ Antarct Surv Bull 79:27-50

Morris RJ, Sargent JR (1973) Studies on the lipid metabolism of some oceanic crustaceans. Mar Biol 22:77-83

Nichols PD, Volkman JK, Everitt DA (1989) Occurrence of cis6 -hexadecenoic acid and other unusual monounsaturated fatty acids in the lipids of oceanic particulate matter Oceanol Acta 12:393-403

Nichols PD, Skerratt JH, Davidson A, Burton H, McMeekin TA (1991) Lipids of cultured Phaeocystis pouchetii: signatures for food-web, biogeochemical and environmental studies in Antarctica and the Southern Ocean. Phytochem 30:3209-3214

Nicol S, Stolp M, Cochran T, Geijsel P, Marshall J (1992) Growth and shrinkage of Antarctic krill Euphausia superba from the Indian Ocean sector of the Southern Ocean during summer. Mar Ecol Prog Ser 89:175-181

Opalinski KW, Maciejewska K, Georgieva LV (1997) Notes on food selection in the Antarctic krill, Euphausia superba. Polar Biol 17:350-357

Pakhomov EA, Perissinotto R, Froneman PW, Miller DGM (1997) Energetics and feeding dynamics of Euphausia superba in the South Georgia region during the summer of 1994. J Plankton Res 19:399-424

Peeken I (1997) Photosynthetic pigment fingerprints as indicators of phytoplankton biomass and development in dif- ferent water masses of the Southern Ocean during austral spring. Deep Sea Res I 44:261-282

Perissinotto R, Pakhomov EA, MCQuaid CD, Froneman PW (1997) In situ grazing rates and daily ration of Antarctic krill Euphausia superba teeding on phytoplankton at the Antarctic Polar Front and the Marginal Ice Zone. Mar Ecol Prog Ser 160:77-91

Pilditch CA, McClatchie S (1994) Quantitative analysis of carnivory in krill Nyctiphanes australis, with an examination of the effect of non-preferred phytoplankton alternative prey. Mar Ecol Prog Ser 107:41-53

Pond D, Priddle J, Sargent J, Watkins JL (1993) Lipid composition of Antarctic microplankton in relation to nutrition of krill. In: Heywood RB (ed) University research in Antarctica, 1989-1992. British Antarctic Survey, Cambridge, p $133-139$

Pond D, Watkins JL, Priddle J, Sargent J (1995) Variation in lipid content and composition of Antarctic krill Euphausia superba at South Georgia. Mar Ecol Prog Ser 117:49-57

Price HJ, Boyd KR, Boyd CM (1988) Omnivorous feeding behaviour of the Antarctic krill Euphausia superba. Mar Biol 97:67-77

Priddle J, Heywood RB, Theriot E (1986) Some environmental factors influencing phytoplankton in the Southern Ocean around South Georgia. Polar Biol 5:65-79

Priddle J, Leakey RGJ, Symon C, Whitehouse MJ, Robins D, Cripps GC, Murphy EJ, Owens N (1995) Nutrient cycling by Antarctic microbial plankton. Mar Ecol Prog Ser 116 $181-198$

Priddle J, Whitehouse MJ, Atkinson A, Brierley AS, Murphy EJ (1997) Diurnal changes in near-surface ammonium concentration - interplay between zooplankton and phytoplankton. J Plankton Res 19:1305-1330

Quetin LB, Ross RM (1985) Feeding by Antarctic krill, Euphausia superba: does size matter? In: Siegfried WR, Condy PR, Laws RM (eds) Antarctic nutrient cycles and food webs. Springer-Verlag, Heidelberg, p 372-377

Quetin LB, Ross RM (1991) Behavioural and physiological characteristics of the Antarctic krill, Euphausia superba. Am Zool 31:49-63

Quetin LB, Ross RM, Clarke A (1994) Krill energetics: seasonal and environmental aspects of the physiology of Euphausia superba. In: El-Sayed SZ (ed) Southern Ocean ecology, the biomass perspective. Cambridge University Press, Cambridge, p 165-184

Reinhardt SB, Van Vleet ES (1986) Lipids composition of twenty two species of Antarctic midwater zooplankton and fish. Mar Biol 91:149-159

Sargent JR, Falk-Petersen S (1981) Ecological investigations on the zooplankton community in Balsfjorden, northern Norway: lipids and fatty acids Meganyctiphanes norvegia. Mar Biol 62:131-137

Sargent JR, Parkes RJ, Mueller-Harvey I, Henderson RJ (1987) Lipid biomarkers in marine ecology. In: Sleigh MA (ed) Microbes in the sea. Ellis Horwood, Chichester, p 119-138

Schnack SB (1985) Feeding by Euphausia superba and copepod species in response to varying concentrations of phytoplankton. In: Siegfried WR, Condy PR, Laws RM (eds) Antarctic nutrient cycles and food webs. SpringerVerlag, Heidelberg, p 311-323

Skerratt JH, Nichols PD, McMeekin TA, Burton H (1995) Seasonal and inter-annual changes in planktonic biomass and community structure in eastern Antarctica using signature lipids. Mar Chem 51:93-113

Smetacek V, Scharek R, Nöthig EM (1990) Seasonal and regional variation in the pelagial and its relationship to the life history of krill. In: Kerry KR, Hempel G (eds) Ant- 
arctic ecosystems - ecological change and conservation. Springer-Verlag, Heidelberg, p 103-114

Tanoue E (1985) Organic chemical composition of fecal pellet of the krill Euphausia superba Dana. Trans Tokyo Univ Fish 6:125-134

Torres JJ, Donnelly J, Hopkins TL, Lancraft TM, Aarset AV, Ainley DG (1994) Proximate composition and overwintering strategies of Antarctic micronektonic crustacea. Mar Ecol Prog Ser 113:221-232

Trathan P, Brandon MA, Murphy EJ (1997) Characterization of the Antarctic Polar frontal zone to the north of South Georgia in summer 1994. J Geophys Res 102: 10483-10497

Virtue P, Nichols PD, Nicol S, McMinn A, Sikes EL (1993) The lipid composition of Euphausia superba Dana in relation to the nutritional value of Phaeocystis pouchetii (Hariot) Lagerheim. Antarct Sci 5:169-178

Virtue P, Nichols PD, Nicol S, Hosie G (1996) Reproductive trade-off in male Antarctic krill, Euphausia superba. Mar Biol 126:521-527

Virtue P, Nichols PD, Nicol S (1997) Dietary-related mechanisms of survival in Euphausia superba: biochemical changes during long term starvation and bacteria as a possible source of nutrition. In: Battaglia B, Valencia J, Walton DWH (eds) Antarctic communities: species, structure and survival. Cambridge University Press, Cambridge, p 193-201

Editorial responsibility: Otto Kinne (Editor),

Oldendorf/Luhe, Germany
Viso AC, Marty JC (1993) Fatty acids from 28 marine microalgae. Phytochemistry 34:1521-1533

Volkman JK, Jeffrey SW, Nichols PD, Rogers GI, Garland CD (1989) Fatty acid and lipid composition of 10 species of microalgae used in mariculture. J Exp Mar Biol Ecol 128: $219-240$

Ward P, Shreeve RS, Cripps GC (1996) Rhincalanus gigas and Calanus simillimus: lipid storage patterns of two species of copepod in the seasonally ice free zone of the Southern Ocean. J Plankton Res 18:1439-1454

Watkins JL, Murray AWA, Daly HI (in press) Variation in the distribution of Antarctic krill Euphausia superba around South Georgia. Mar Ecol Prog Ser

Weber LH, El-Sayed SZ (1985) Spatial variability of phytoplankton and the distribution and abundance of krill in the Indian sector of the Southern Ocean. In: Siegfried WR, Condy PR, Laws RM (eds) Antarctic nutrient cycles and food webs. Springer-Verlag, Heidelberg, p 284-293

Whitehouse MJ, Priddle J, Symon C (1996) Seasonal and annual change in seawater temperature, salinity, nutrient and chlorophyll a distributions around South Georgia, South Atlantic. Deep-Sea Res [ 43:425-443

Wright SW, Jeffrey SW, Mantoura RFC, Llewellyn CA, Bjørnland T, Repeta D, Welschmeyer N (1991) Improved HPLC method for the analysis of chlorophylls and carotenoids from marine phytoplankton. Mar Ecol Prog Ser 77 : $183-196$

Submitted: October 7, 1998; Accepted: February 1, 1999 Proofs received from author(s): May 4, 1999 